\title{
Protective immunity and vaccination against cutaneous leishmaniasis
}

\author{
Ifeoma Okwor ${ }^{1}$, Zhirong Mou ${ }^{2}$, Dong Liu' ${ }^{2}$ and Jude Uzonna ${ }^{1,2 *}$ \\ ${ }_{1}^{1}$ Department of Medical Microbiology, University of Manitoba, Winnipeg, MB, Canada \\ ${ }^{2}$ Department of Immunology, University of Manitoba, Winnipeg, MB, Canada
}

\section{Edited by:}

Nathan Peters, National Institute of

Allergy and Infectious Diseases, USA

Reviewed by:

Phillip Scott, University of

Pennsylvania, USA

Buenos Aires, Argentina

Abhay Satoskar, The Ohio State

University, USA

Jude Uzonna, Parasite Vaccines

Development Laboratory, Department

of Immunology, University of

Manitoba, 750 McDermot Avenue,

Winnipeg, MB, Canada R3E OT5.
Emilio Luis Malchiodi, University of

*Correspondence:

e-mail: uzonna@cc.umanitoba.ca

Although a great deal of knowledge has been gained from studies on the immunobiology of leishmaniasis, there is still no universally acceptable, safe, and effective vaccine against the disease. This strongly suggests that we still do not completely understand the factors that control and/or regulate the development and sustenance of anti-Leishmania immunity, particularly those associated with secondary (memory) immunity. Such an understanding is critically important for designing safe, effective, and universally acceptable vaccine against the disease. Here we review the literature on the correlate of protective anti-Leishmania immunity and vaccination strategies against leishmaniasis with a bias emphasis on experimental cutaneous leishmaniasis.

\section{Keywords: cutaneous leishmaniasis, innate immunity, adaptive immunity, infection-induced resistance, vaccine,} vaccination

\section{INTRODUCTION}

Protozoan parasites in the genus Leishmania are the causative agents of a spectrum of human diseases collectively known as leishmaniasis. The disease is endemic in 88 countries, affects 12 million people currently, and over 350 million more at risk (Desjeux, 1996). It is important to note that these estimates may not reflect the true burden of the disease due to underreporting (Singh et al., $2006,2010)$. Also, the fact that leishmaniasis is reportable in only 33 out of the 88 endemic countries more prevalent in very low income group means that there are many undiagnosed as well as asymptomatic cases since transmission occur in rural areas where there is little or no access to medical care ${ }^{1}$.

Leishmaniasis can manifest in three major clinical forms: the self-healing simple cutaneous leishmaniasis (CL) that occurs as skin lesions, the mucocutaneous leishmaniasis (MCL) that affects mucous membranes of the oral and nasal cavities and the deadly visceral leishmaniasis (VL) that affects visceral organs such as spleen and liver (Reithinger et al., 2007). CL is the most common clinical form of the disease and the most studied experimentally. In contrast, VL is the most clinically relevant disease because of its high morbidity and mortality. Over $90 \%$ of CL occur mostly in seven countries namely Afghanistan, Algeria, Brazil, Iran, Peru, Saudi Arabia, and Syria, whereas most (>95\%) of the VL cases is concentrated in Bangladesh, India, Nepal, Sudan, Ethiopia, and Brazil (Chappuis et al., 2007). Although treatment is available, the current drugs used for treatment are highly toxic, expensive, and cases of resistance have been reported (Lira et al., 1999). Recent epidemics have been reported in endemic areas and there is evidence of spread of leishmaniasis into previously

${ }^{1}$ http://apps.who.int/gb/ebwha/pdf_files/WHA60/A60_10-en.pdf non-endemic areas. For instance soldiers returning from active duty in endemic areas have been diagnosed with leishmaniasis (van Thiel et al., 2010; Bailey, 2011). Furthermore, Human Immunodeficiency Virus (HIV)/Leishmania co-infection is an alarming threat in some countries in Africa and Asia where HIV/AIDS is also endemic. As such, VL is now included as an important opportunistic infection in HIV infected patients ${ }^{2}$. Currently, only three anti-Leishmania vaccines have been approved and licensed. These include two human vaccines; a killed vaccine for immunotherapy in Brazil and a live vaccine in Uzbekistan; and a recombinant vaccine for prophylaxis in dogs in Brazil (Palatnik-de-Sousa, 2008). However, the efficacy of these vaccines remains controversial, particularly when compared with those against viral and bacteria infections. The lack of an effective prophylactic vaccine suggests that we still do not fully understand the factors that regulate the induction and maintenance of antiLeishmania immunity. Understanding these factors is critical for the design of effective vaccine and/or vaccination strategy against leishmaniasis.

\section{INNATE IMMUNITY TO LEISHMANIA INFECTION NEUTROPHILS, MACROPHAGES AND DENDRITIC CELLS}

Leishmania parasites are transmitted to humans and other vertebrate host through the bite of sand fly vectors. The sand fly inoculum contains live, apoptotic or dead promastigotes (van Zandbergen et al., 2006), and salivary components (Lerner and Shoemaker, 1992), which play critical roles in shaping the host's immune response (Mougneau et al., 2011). Following the injection of metacyclic promastigotes into the skin, they interact with

\footnotetext{
${ }^{2}$ http://www.who.int/leishmaniasis/burden/en/
} 
multiple cell types (neutrophils, macrophages, dendritic cells, keratinocytes, and langerhans cells) where they then transform into intracellular amastigotes (Mougneau et al., 2011). In particular, phagocytosis of parasites by macrophages induces the release of multiple chemoattractant factors such as MCP-1 and CXCL1, leading to recruitment of monocytes and neutrophils (Racoosin and Beverley, 1997). Both in vitro and in vivo studies have shown that neutrophils influence the outcome of Leishmania infection through several ways including intracellular killing after phagocytosis, extracellular killing through the release of neutrophil extracellular traps (NETS), and through cooperation with macrophages (John and Hunter, 2008; Peters et al., 2008; Mougneau et al., 2011). In addition, the uptake of promastigotes by neutrophils inhibits cellular apoptotic signals thereby prolonging their lifespan (Aga et al., 2002). These "long-lived" neutrophils become transiently unable to kill Leishmania and acts as "Trojan horses" for dissemination of parasites to other cells, particularly macrophages (Aga et al., 2002; van Zandbergen et al., 2004). Interestingly, a recent work suggests that contrary to the observations in Leishmania major, neutrophils may play a protective role in L. braziliensis infection (Novais et al., 2009), suggesting that these innate immune cells may play distinct roles in CL caused by L. major and L. braziliensis.

Although neutrophils are the most abundant cells at the infection site during the first few hours to days, the pattern, and magnitude of monocyte influx may be more important in shaping the outcome of infection. About 1 week after infection, monocytes invade the infection site (Leon et al., 2007) where they differentiate into monocytes-derived dendritic cells (mDCs) that take up parasites (Mougneau et al., 2011). Via a TLR-9-dependent pathway, mDCs play a vital role in the production of IL-12 and Type 1 IFNs, leading to activation of Natural Killer (NK) cells, the production of Interferon gamma (IFN- $\gamma$ ), and the subsequent Th1 response (Liese et al., 2008). In general, DCs are essential for the initiation and regulation of anti-Leishmania adaptive immunity (Kane and Mosser, 2000). The magnitude of IL-12 production by infected DCs critically affects the outcome L. major infection. Dendritic cells from the susceptible BALB/c mice produce less IL-12 following $L$. major infection and their $\mathrm{T}$ cells respond very poorly to IL-12 due to the down regulation of the IL-12 receptor $\beta$ (IL$12 \mathrm{R} \beta$ ) chain. In contrast, the resistant $\mathrm{C} 57 \mathrm{BL} / 6$ mice produce more and maintain their IL-12 responsiveness throughout the course of infection (Himmelrich et al., 1998).

The tissue resident macrophages are the definitive host cells for parasite survival and replication. In addition, classical activation of infected macrophages by IFN- $\gamma$ and tumor necrosis factor (TNF) stimulates the production of inducible nitric oxide (iNOS), an enzyme that catalyzes $\mathrm{L}$-arginine to generate nitric oxide (NO; Liew et al., 1990a). NO is a powerful cytostatic and cytotoxic molecule and plays a major role in killing many intracellular parasites, including Leishmania. Thus, in leishmaniasis, macrophages play a dual role; they represent an important cell population responsible for killing of the parasites and also the major site of parasite replication (Birnbaum and Craft, 2011).

\section{NATURAL KILLER (NK) CELLS}

Natural Killer cells are important innate components and their contribution to protective immunity against Leishmania infection has been studied extensively. NK cells purified from unexposed human PBMCs proliferate and secrete IFN- $\gamma$ in response to Leishmania antigen (Nylen et al., 2003). Depletion of NK cells within the first 7 days of $L$. major infection in mice leads to significant reduction in IFN- $\gamma$ production and higher parasite burden (Laurenti et al., 1999) suggesting an important role of NK cells during the early innate response to Leishmania infection. In support of this, a robust NK cell IFN- $\gamma$ response was associated with enhanced resistance to $L$. major infection in the $\mathrm{C} 3 \mathrm{H} / \mathrm{HeN}$ mice whereas diminished NK activity was observed in the susceptible BALB/c mice (Scharton and Scott, 1993). NK cells can also control infection by directly lysing infected macrophages or parasites (Scharton and Scott, 1993), although this effect seem to be parasite species dependent (Korbel et al., 2004).

\section{ADAPTIVE IMIMUNITY TO CUTANEOUS LEISHMANIASIS}

Because Leishmania are obligate intracellular parasites, cellmediated immunity is required for control of the infection and hence $\mathrm{T}$ cells are indispensable for resistance. T cell deficient mice are highly susceptible to Leishmania infection, and adoptive transfer of T cells restores resistance in these mice (Varkila et al., 1993). Both $\mathrm{CD}^{+}{ }^{+}$and $\mathrm{CD}^{+}{ }^{+} \mathrm{T}$ cells are important for optimal primary immunity to $L$. major although their relative contribution may depend on experimental conditions and parasite strains/species.

\section{CD4 $^{+}$T HELPER CELLS AND RESISTANCE TO L. MAJOR}

Following the identification of distinct mouse $\mathrm{CD} 4^{+} \mathrm{T}$ helper cell subsets by Mosmann et al. (1986), it was demonstrated that IFN$\gamma$ production by $\mathrm{CD} 4^{+} \mathrm{T}$ cells was associated with healing of $L$. major-infected C57BL/6 mice, while IL-4 production was associated with susceptibility in the BALB/c mice (Heinzel et al., 1989). Scott et al. (1988) demonstrated that adoptive transfer of polarized $\mathrm{T}$ cell clones can change the outcome of L. major infection: Th1 clones were "protective" while Th2 clones were "non-protective" (Scott et al., 1988). Holaday et al. (1991) further confirmed this finding by transferring Th1-like or Th2-like cell lines into SCID mice, which resulted in the recipient mice becoming resistant or susceptible, respectively. Thus, the balance of Th1/Th2 cytokines determines disease outcome in mouse model of CL: healing in resistant mice is associated with the development of $\mathrm{CD} 4^{+} \mathrm{Th} 1$ cells that produce IFN- $\gamma$ whereas susceptibility is associated with an early IL- 4 production by $\mathrm{CD} 4^{+} \mathrm{T}$ cells that promotes the development and expansion of Th2 cells (Locksley et al., 1995).

The overarching question has been what factors direct the preferential Th1 and Th2 cell development in the resistant and susceptible mice, respectively, following infection. The single most dominant factor appears to be the production of IL-12 by DCs and responsiveness to this cytokine by $\mathrm{T}$ cells during the initial phase of infection. Dendritic cells from the highly susceptible $\mathrm{BALB} / \mathrm{c}$ produces less IL-12 and their T cells respond poorly to this cytokine due to low expression of IL-12R $\beta$ chain (Himmelrich et al., 1998). In contrast, infected C57BL/6 mice produce more and maintain their IL-12 responsiveness throughout infection (Louis et al., 1998a,b). Indeed, treatment of infected BALB/c mice with rIL-12 early during infection renders them resistant (Afonso et al., 1994) whereas administration of anti-IL-12 antibodies renders B6 mice susceptible (Heinzel et al., 1995). 
While IL-12 is the dominant cytokine that drives Th1 development leading to resistance, the factors that drive expansion of Th2 cells in the susceptible mice are not completely understood. Studies show that the early production of IL-4 by unique population of $\mathrm{CD}^{+}{ }^{+} \mathrm{T}$ cells promotes the development and expansion of Th2 cells in the susceptible mice (Scott, 1989; Scott et al., 1989; Reiner and Locksley, 1995; Himmelrich et al., 2000). These cells respond to peptides derived from the Leishmania homolog of activated protein kinase (LACK) protein by producing high levels of IL-4 leading to concomitant expansion of Th2 cells (Mougneau et al., 1995). However, the contribution of these cells to susceptibility in other strains of mice has been equivocal. Both IL-4 and IL-13 synergize in mediating susceptibility to L. major infection (Matthews et al., 2000), although the relative contribution of IL-13 has been recently challenged (Sosa et al., 2001) and may indeed be dependent on parasite specie (Alexander et al., 2002).

\section{CD8 $^{+}$T CELLS AND RESISTANCE TO L. MAJOR}

Because activated $\mathrm{CD}^{+} \mathrm{T}$ cells also produce IFN- $\gamma$ (a critical macrophage activating cytokine for intracellular parasite destruction), it was speculated that they would also contribute to optimal immunity to L. major. Interestingly, several studies demonstrated that mice lacking $\mathrm{CD}^{+} \mathrm{T}$ cells or MHC-Class I expression were not impaired in their ability to control primary L. major infections (Wang et al., 1993; Huber et al., 1998). However, recent studies utilizing low dose intradermal infection that closely mimic natural infections show that $\mathrm{CD}^{+} \mathrm{T}$ cells are important for anti-Leishmania immunity. Inoculation of low dose metacyclic promastigotes into the ear dermis of CD8 deficient C57BL/6 mice leads to uncontrolled parasite proliferation. We found that low dose infection-induced a transient Th2 response in naive wild type (WT) mice (Uzonna et al., 2004a). In the absence of CD8 ${ }^{+}$ $\mathrm{T}$ cells, the transient Th2 response was sustained, suggesting that the major role of $\mathrm{CD}^{+} \mathrm{T}$ cells is to produce IFN- $\gamma$ that downmodulates the early CD $4^{+}$Th2 cell development (Uzonna et al., 2004a).

\section{ROLE OF CYTOKINES \\ INTERFERON GAMMA (IFN- $\gamma$ )}

Interferon gamma is a critical cytokine for resistance to L. major infection in mice because it plays a crucial role for macrophage activation leading to the production of microbicidal molecules. In addition, IFN- $\gamma$ is also necessary for the down regulation of Th2 cytokines and suppression of Th2 cell development. A single injection of anti-IFN- $\gamma$ antibodies to resistant mice 2 days prior to L. major infection resulted in Th2 response and increased susceptibility (Belosevic et al., 1989; Scott, 1991). In contrast, administration of rIFN- $\gamma$ at the time of infection of the susceptible mice dramatically reduced lesion sizes and parasite burden (Scott, 1991). Furthermore, IFN- $\gamma$ or IFN- $\gamma$-R deficient mice on the usually resistant C57BL/6 background develop progressive lesion associated with uncontrolled parasite proliferation after L. major infection (Swihart et al., 1995).

TUMOR NECROSIS FACTOR SUPERFAMILY OF CYTOKINES (TNFSF)

Members of the TNF superfamily of cytokines and their cognate receptors also play significant roles in modulating disease outcome in experimental CL. TNF has been shown to play a protective role by synergizing with IFN- $\gamma$ in mediating parasite killing (Liew et al., 1990a,b). Peritoneal macrophages from TNFR1 deficient mice are grossly defective in NO production and their ability to kill parasites in vitro. In contrast, macrophages from TNFR2 deficient mice are normal; suggesting that TNF-dependent macrophage activation for in vitro parasite killing is mediated via signaling through TNFR1 (Nashleanas and Scott, 2000). Treatment of infected mice with recombinant TNF resulted in reduced lesion size and lower parasite burden, while the administration of anti-TNF antibodies results in larger lesions and higher parasite burden (Titus et al., 1989). Disruption of the TNF gene in the resistant mice leads to visceralization of $L$. major infection and death within a few weeks (Wilhelm et al., 2001).

Recently, we showed that both lymphotoxin beta (LT $\beta)$, and LIGHT (LT-like, exhibits inducible expression and competes with HSV glycoprotein D for herpes virus entry mediator, a receptor expressed by T lymphocytes) contribute to resistance to $L$. major. LT $\beta$ deficient mice on the resistant C57BL/ 6 background developed chronic non-healing lesion after infection with L. major and this was associated with decreased IL-12 and antigen-specific IFN$\gamma$ production (Xu et al., 2007a). In contrast, blockade of LIGHT signaling led to acute and fatal leishmaniasis, which was associated with uncontrolled parasite proliferation, severely impaired IL-12 production, and poor CD4 ${ }^{+}$Th1 cell response (Xu et al., 2007b). While intra-lesional treatment of infected mice with rIL-12 completely reversed the susceptibility of LIGHT deficient mice to $L$. major, it only partially reduced parasite proliferation in infected LT $\beta$ deficient mice proliferation (Xu et al., 2007a), suggesting that LIGHT and LT $\beta$ may exert their effects through different but nonmutually exclusive manner. The differences in the outcome of infection in LIGHT and LT $\beta$ deficient mice suggests that LIGHT plays a more important role in regulating outcome of L. major infection than LT $\beta$.

\section{INTERLEUKIN (IL)-4 AND IL-13}

In contrast to elevated IFN- $\gamma$ level in L. major-infected resistant mice, high levels of IL-4 are found in infected susceptible $\mathrm{BALB} / \mathrm{c}$ mice and is associated with disease progression. Administration of IL-4 neutralizing antibodies renders susceptible BALB/C mice resistant to L. major (Heinzel et al., 1993). Surprisingly, IL-4 deficient BALB/c mice remain susceptible to L. major (LV39 substrain) infection (Noben-Trauth and Kropf, 1996). In contrast, IL- $4 \mathrm{R} \alpha$ deficient BALB/c mice are highly resistant to L. major substrain IR173, suggesting that another cytokine that signal through IL- $4 \mathrm{R} \alpha$ contributes to the susceptibility in BALB/mice. Signaling through IL-4R $\alpha$ subunit is shared between IL- 4 and IL-13, and IL-13 is a major Th2 cytokine (Mueller et al., 2002). Indeed, studies show that IL-13 promotes disease in L. major-infected mice (Mohrs et al., 1999; Noben-Trauth et al., 1999; Matthews et al., 2000; Brombacher, 2003). Interestingly, murine lymphocytes do not express any IL-13 receptors (Brombacher, 2000), indicating that the effects of IL-13 are mediated indirectly through other cell types, most likely APCs. IL-13 has been found to down-regulate macrophage functions including IL-12 (Skeen et al., 1996), iNOS (Paludan et al., 1997; Rutschman et al., 2001), and TNF (Doyle et al., 1994; Di Santo et al., 1997) production. In addition, IL-13 
up-regulates $\mathrm{PGE}_{2}$ production (Rey et al., 1999), which could in turn inhibit IL-12R $\beta 2$ expression on T cells (Wu et al., 1998) leading to impaired Th1 cell development and susceptibility to L. major infection (Farrell and Kirkpatrick, 1987; Milano et al., 1996).

\section{INTERLEUKIN-10}

Another key cytokine that regulate disease outcome in Leishmania-infected mice is IL-10. The susceptibility of BALB/c mice to $L$. major is IL-10 dependent, because IL- $4 \mathrm{R} \alpha$ deficient BALB/c mice remain highly susceptible to $L$. major infection and this susceptibility could be abolished by treatment with anti-IL-10R antibody (Noben-Trauth et al., 2003). In addition, IL-10 deficient BALB/c mice are resistant to L. major infection despite intact IL-4 signaling (Noben-Trauth et al., 2003). IL-10 mediates its effect by blocking macrophage activation by IFN- $\gamma$ thereby preventing the production of parasiticidal NO (Chatelain et al., 1999). IL-10 also directly inhibits the development of Th1 cells and their production of IFN- $\gamma$ (Fiorentino et al., 1991; Mosmann and Moore, 1991). Both macrophages (Von Stebut, 2007) and CD4 ${ }^{+}$Th2 cells (Anderson et al., 2007) are important sources of IL-10 in Leishmania-infected mice. Interestingly, IL-10 $10^{-1-}$ mice on C57BL/6 background do not show any enhanced resistance to L. amazonensis, despite mounting a stronger Th1-type response (Jones et al., 2002). Moreover, another study reported that IL-10 $-1-\mathrm{BALB} / \mathrm{c}$ mice infected with $L$. mexicana and L. amazonesis fail to control the disease progression but the lesions were less severe than their WT controls, suggesting the genetic background and parasite species may influence the requirement for IL-10 in resistance (Padigel et al., 2003). Healing from primary infection with $L$. major is typically accompanied with parasite persistence (Aebischer et al., 1993). IL-10 produced by regulatory $\mathrm{T}$ ( $\mathrm{T}_{\text {regs }}$ ) cells has also been linked to parasite persistence at the primary site of infection (Belkaid et al., 2002). IL-10 produced by Treg is responsible for a persistent chronic infection. Taken together, these data clearly indicate a central role for IL-10 in susceptibility, immunopathology, and parasite persistence in $L$. major-infected mice.

\section{ROLE OF IL-17 AND TH17 CELLS}

T helper 17 (Th17) cells are new T helper cell subsets that produce interleukin IL-17A (also called IL-17), a pro-inflammatory cytokine that play important pathologic role in several immunemediated disease (Chang et al., 2011; Zhang et al., 2011). However, their protective function in various infectious diseases has also been reported (Mou et al., 2010; Wu et al., 2010). T cells from infected susceptible BALB/c mice produce more IL-17 than those from the resistant C57BL/6 mice and L. major-infected IL-17 deficient BALB/c mice develop smaller lesions and harbor lower parasites compared to their WT counterpart mice (Lopez Kostka et al., 2009). The increased resistance to L. major in IL-17 deficient mice was associated with decreased CXCL2 accumulation and fewer neutrophils in lesions (Lopez Kostka et al., 2009). In contrast, some studies provide indirect evidence that IL-17 may be associated with enhanced susceptibility to L. major infection (Akilov et al., 2009; Anderson et al., 2009; Makala et al., 2011; Reinhard et al., 2011). The pathogenic role of IL-17 has also been found in human mucosal leishmaniasis (Boaventura et al., 2010). Interestingly, Th17 and IL-17 have been shown be associated with enhanced control of L. donovani (Pitta et al., 2009) infections in mice. Also the self-healing of $L$. braziliensis infection in mice has been strongly correlated with the expansion of Th17 cells (VargasInchaustegui et al., 2008). Thus, it appears that the role of IL-17 may be related to the specie of Leishmania organism.

\section{REGULATORY T CELLS IN LEISHMANIA INFECTION}

Regulatory $\mathrm{T}$ cells are a specialized $\mathrm{CD} 4^{+} \mathrm{CD} 25^{+} \mathrm{Foxp}^{+} \mathrm{T}$ cell subsets that suppress the activation of immune system and therefore are important for maintaining immune homeostasis and self-tolerance. During L. major infection, $\mathrm{CD} 4{ }^{+} \mathrm{CD} 25^{+} \mathrm{T}_{\text {regs }}$ accumulate at the primary infection site in both human and mouse, where they suppress parasite elimination by $\mathrm{CD} 4{ }^{+} \mathrm{CD} 25^{-}$effector $\mathrm{T}$ cells, mediate disease chronicity, and their depletion leads to parasite clearance (Belkaid et al., 2002; Anderson et al., 2005; Campanelli et al., 2006; Bourreau et al., 2009). $\mathrm{T}_{\text {regs }}$ are also directly responsible for Leishmania reactivation (Mendez et al., 2004; Lages et al., 2008) because transfer of $\mathrm{T}_{\text {regs }}$ purified from infected mice into healed mice is sufficient to trigger disease reactivation (Mendez et al., 2004). Interestingly, it was shown that proliferation and cytokine (IL-10) production by these $T_{\text {regs }}$ occur in Leishmania-specific manner (Suffia et al., 2006).

Several studies have shown that homing of $\mathrm{T}_{\text {regs }}$ to L. majorinfected dermal sites promotes establishment of infection and long-term survival of the parasite (Suffia et al., 2005; Yurchenko et al., 2006). The expression of alpha and beta integrin is necessary for homing of $\mathrm{T}_{\text {regs }}$ to the site of L. major infection (Suffia et al., 2005). CD103 deficient BALB/c mice are resistant to $L$. major infection and the susceptible phenotype can be restored by adoptive transfer of $\mathrm{WT} \mathrm{T}_{\text {regs }}$ into $\mathrm{CD} 103^{-/-}$mice (Suffia et al., 2005). Natural $T_{\text {regs }}$ preferentially express the chemokine receptor, CCR5, compared to conventional CD ${ }^{+} \mathrm{T}$ cells. Adoptive transfer of CCR5 ${ }^{-1-} \mathrm{T}_{\text {regs }}$ results in an increased magnitude of parasitespecific, IFN- $\gamma$-producing $\mathrm{CD} 4^{+} \mathrm{T}$ cells at the infection sites and significant reduction in parasite numbers, which is consistent with the enhanced resistance of CCR5 $5^{-1-}$ mice to L. major infection (Yurchenko et al., 2006).

Recently, we found that mice with an inactivating knock-in mutation in the $\mathrm{p} 110 \delta$ isoform of PI3K (termed $\mathrm{p} 110 \delta^{\mathrm{D} 910 \mathrm{~A}}$ ) are highly resistant to L. major (Liu et al., 2009). The enhanced resistance of $\mathrm{p} 110 \delta^{\mathrm{D} 910 \mathrm{~A}}$ mice is related to defects in homing, expansion, and/or function of $\mathrm{T}_{\text {regs }}$, suggesting that signaling via the $\mathrm{p} 110 \delta$ isoform of $\mathrm{PI} 3 \mathrm{~K}$ may regulate expansion and tissue homing of $\mathrm{T}_{\text {regs }}$ (Liu et al., 2009). Indeed, $\mathrm{CD} 4^{+} \mathrm{CD} 25^{+}$cells from infected WT mice could transfer susceptibility to $\mathrm{p} 110 \delta^{\mathrm{D} 910 \mathrm{~A}}$ mice. In contrast, transfer of $\mathrm{CD} 4{ }^{+} \mathrm{CD} 25^{+} \mathrm{T}$ cells from naive (uninfected) WT or infected $\mathrm{p} 110 \delta^{\mathrm{D} 910 \mathrm{~A}}$ mice into naïve $\mathrm{p} 110 \delta^{\mathrm{D} 910 \mathrm{~A}}$ mice failed to abolish their enhanced resistance to $L$. major. These observations suggest that $\mathrm{CD} 4^{+} \mathrm{T}$ cells from $\mathrm{p} 110 \delta^{\mathrm{D} 910 \mathrm{~A}}$ mice are intrinsically defective in their ability to differentiate into inducible $\mathrm{T}_{\text {regs }}$ following infection with L. major.

\section{INFECTION-INDUCED RESISTANCE IN CUTANEOUS LEISHMANIASIS}

Recovery from natural or experimental infections in humans and mice is associated with the development of strong and durable immunity to re-challenge infection. This so-called infectioninduced resistance is the fundamental principle underlying 
leishmanization, a practice in which individuals are deliberately injected with live organisms to protect against more serious ulcers after natural infection (Momeni and Aminjavaheri, 1995). Understanding the factors that regulate and mediate infection-induced resistance is critically important for designing an effective vaccine and vaccination strategies against leishmaniasis.

Infection-induced resistance in mice is mediated by IFN- $\gamma$ producing $\mathrm{CD}^{+}{ }^{+} \mathrm{T}$ cells (Belosevic et al., 1989) and its maintenance is dependent on IL-12 produced by antigen presenting cells. Thus, the highly susceptible IL-12 deficient mice treated with rIL12 develop Th1 response and resolve their lesion. However, in contrast to WT mice, these rIL-12-treated mice develop progressive disease and uncontrolled parasite replication upon re-challenge infection (Park et al., 2000). In fact, lesion disease reactivation occur at the primary infection site in healed IL-12-deficient mice upon cessation of IL-12 treatment (Park et al., 2000), suggesting that exogenous administration of rIL-12 was able to only promote short-term resistance. It is conceivable that IL-12 may be required for optimal proliferation and differentiation of memory CD4 ${ }^{+} \mathrm{T}$ into IFN- $\gamma$ producing effector cells. Alternatively, IL-12 could be acting to enhance the development and survival of Leishmaniaspecific effector memory cells that are important for mediating rapid secondary anti-Leishmania immunity (Zaph et al., 2004; Liu and Uzonna, 2010).

Under certain conditions, infection-induced resistance can be lost and previously immune animals become highly susceptible to re-challenge infections (Uzonna et al., 2001; Belkaid et al., 2002). This loss of resistance has been linked to complete parasite clearance, suggesting that persistent parasites are important for the maintenance of anti-Leishmania immunity. Recent studies from our group show that infection-induced resistance could also be lost in the presence of persistent parasites (Okwor et al., 2009). Injection of killed parasites into mice that have healed their primary L. major infection results in rapid expansion of IL-10-producing $\mathrm{T}_{\text {regs }}$, a concomitant loss of infection-induced resistance and susceptibility to virulent L. major challenge (Okwor et al., 2009). Injection of avirulent live parasites does not cause loss of infectioninduced resistance (Okwor et al., 2009); suggesting that killed and live parasites may be presented differently to $\mathrm{T}$ cells, particularly $\mathrm{T}_{\text {regs }}$ differently.

\section{VACCINES FOR LEISHMANIASIS}

Although experimental L. major infection has extensively enhanced our understanding of the factors that control the development of $\mathrm{CD} 4^{+} \mathrm{T}$ helper cells in vivo, there is still no universally acceptable, safe, and effective vaccine against human leishmaniasis. Several vaccination trials in humans using killed Leishmania parasites yielded very disappointing results (Handman, 2001). In murine studies, several experimental vaccines are effective, but many of them rely on IL-12, or components that induce IL-12, as adjuvant (Afonso et al., 1994; Gurunathan et al., 1997, 1998; Scott, 1997). However, as with killed Leishmania vaccines, the protection wanes with time. These studies suggest that we need to know more about the requirements for maintenance of anti-Leishmania immunity in order to better define the correlates of protection. In the following sections, we review information on vaccination strategies against CL and comment on their implications for developing effective vaccine against the disease.

\section{LEISHMANIZATION}

Leishmanization which is the oldest and perhaps most effective vaccination strategy against $\mathrm{CL}$, is the injection of live virulent parasites or tissue extracts from infected lesions into hidden parts of the body of non-immune individual with the aim of preventing the formation of visible lesions following natural infection. This practice was used successfully for a long time to contain epidemics of CL in the republics of the former Soviet Union, Israel, and Iran. However, the development of chronic (non-healing) lesions that require medical treatment and immunosuppression in a large percentage of leishmanized individuals (Greenblatt, 1980) has led to the abandonment of this practice. However, the practice is gradually making a comeback in certain endemic regions such as Iran (Tabbara et al., 2005), because despite the associated morbidities, leishmanization remains the only effective vaccine with proven efficacy in humans to date. Attempts are being made to make leishmanization safer, including the addition of killed parasites (Khamesipour et al., 2005) and the use of adjuvants such as CpG that promote rapid onset of anti-Leishmania immunity and swift healing of lesions (Mendez et al., 2003). CpG acts by inducing IL12 and IFN- $\gamma$ production by dermal DCs, NK, and CD4 ${ }^{+} \mathrm{T}$ cells, respectively (Laabs et al., 2009). In addition, CpG ODN may also promote IL-6 production leading to expansion of Th17 cells (Wu et al., 2010), and blockade of IL-6 production or signaling resulted in increased lesion development in mice infected with L. major (Wu et al., 2006, 2009). The use of genetically attenuated parasites may help eliminate the unwanted side effects associated leishmanization. Attenuated parasites such as $l p g 2-L$. major persist at the local site of injection and its draining lymph node, does not cause pathology and protect mice against virulent $L$. major challenge (Spath et al., 2003a; Uzonna et al., 2004b).

\section{KILLED WHOLE PARASITE VACCINES}

Killed parasite vaccines, also known as the first generation vaccines, represent the first bold step to tackle epidemics of CL by vaccination in endemic countries. Several factors were responsible for this vaccination strategy: it is easy and cheap to make, does not require sophisticated technology, and there is no worry about lesion development and reversion to virulence. However, standardization of parasite-derived vaccines from one culture to another is a major drawback that could impede the registration and marketing of killed vaccines. The use of killed parasites as vaccine dates back to the late 1930s in Brazil. A vaccine containing promastigotes of five killed Leishmania strains was shown to be safe and immunogenic as measured by the leishmanin skin test (LST) reactivity, but conferred only a small degree of protection (50\%). Phase III clinical trials in Ecuador and Colombia showed that heat-killed $L$. amazonensis vaccine was safe, induced strong IFN- $\gamma$ response but did not prevent clinical disease (Velez et al., 2000; Armijos et al., 2004). The apparent lack of protection despite strong Th1 response is consistent with similar observations in mice and primates, and suggests that the induction of Th1 immune response may be necessary but not sufficient for protection against CL. In contrast to the reported benefits of heat-killed vaccines in South America, 
studies utilizing heat-killed L. major with or without BCG in Iran and East African countries yielded disappointing results (Momeni et al., 1999; Khalil et al., 2000). Studies in Vervet monkeys show that killed Leishmania vaccine induced robust Th1 response but could not protect against virulent challenge (Sjolander et al., 1998; Gicheru et al., 2001). However, some reports show that vaccination with heat-killed parasites with strong adjuvants induces Th1 response and protects against virulent challenge in BALB/c mice but this wanes with time. The failure of killed parasites to induce long-term protection may be related to their inability to maintain memory cells (Okwor and Uzonna, 2008). However, we recently showed that repeated injection of killed parasites leads to robust expansion of effector-like memory $\mathrm{T}$ cells resulting in durable protection against virulent challenge (Okwor et al., 2010). Thus, provided enough effector memory-like cells are generated and continuously re-stimulated, there is no obligatory requirement for live parasites for maintaining anti-Leishmania immunity. These findings provide strong rationale for continued evaluation of mechanisms of secondary protective immunity against L. major and suggest that killed parasite-based vaccines could have promising benefits if appropriate vaccination strategies that enhance the generation of optimal memory $\mathrm{T}$ cells are employed.

\section{LIVE-ATTENUATED PARASITE VACCINE}

In order to harness the desirable attributes of leishmanization (parasite persistence and durable immunity) without the potential safety concerns (Muyombwe et al., 1997; Davoudi et al., 2005), different vaccination strategies involving attenuated parasites have been taken. These include long-term in vitro culture with or without antibiotic pressure (Daneshvar et al., 2009), irradiation (Rivier et al., 1993), chemical mutagenesis (Elhay et al., 1990), and more recently targeted deletion of essential virulence genes (Titus et al., 1995). Among these, targeted gene deletion has shown much promise because of the reduced risk of reversal to virulence. Kedzierski et al. (2008) showed that immunization with phosphomannomutase-deficient $L$. major protected the highly susceptible $\mathrm{BALB} / \mathrm{c}$ mice against virulent challenge. The protection was associated with suppression of early IL-10 and IL-13 production as well as expansion of $\mathrm{CD} 44^{\mathrm{hi}} \mathrm{CD} 4^{+}$and $\mathrm{CD} 8^{+} \mathrm{T}$ cells. In a similar study, Leishmania parasite that lacks the gene that encodes for dihydrofolate reductase-thymidylate synthetase ( $d h f r$ $t s$ ), which is essential for long-term parasite survival, was tested as potential vaccines (Titus et al., 1995; Brodskyn et al., 2000). This mutant parasite showed limited protection in mice against L. major and L. amazonensis infection but failed to protect non-human primates against virulent challenge (Amaral et al., 2002). This lack of protection may be attributed to the rapid elimination of the parasites from the host because parasite persistence is associated with maintenance of anti-Leishmania immunity (Aebischer et al., 1993; Uzonna et al., 2001). The deletion of LPG2 gene that encodes an enzyme involved in the transport of GDP-mannose to the Golgi apparatus produced mutant parasites (termed $l p g 2-$ ) that are able to persist indefinitely in infected mice without causing obvious pathology (Spath et al., 2003a). Vaccination of mice with these mutant parasites induced very strong protection against virulent $L$. major challenge (Spath et al., 2003b). Interestingly, the protection induced by $l p g 2-$ parasites was not associated with delayed-type hypersensitivity (DTH) and enhanced IFN- $\gamma$ responses, suggesting that the induction of Th1-like responses might not always be essential or correlate with protective immunity (Kedzierski et al., 2006). Whether lpg2- could mediate protection in non-human primates has not yet been investigated. This information is important if lpg2- parasites could replace virulent organisms for leishmanization in disease endemic countries. Recent report showed that some $l p g 2-$ mutants could regain virulence through a compensatory but as yet undefined mechanism(s) (Spath et al., 2004). Thus, caution must be exercised in using this mutant parasite as a potential liveattenuated vaccine. The gene encoding cysteine proteinase in $L$. mexicana has also been targeted to create attenuated parasite for vaccination studies (Alexander et al., 1998). Cysteine proteinase deficient L. mexicana are highly attenuated in vitro and induced protection against a homologous challenge in hamsters (Saravia et al., 2006) and mice (Alexander et al., 1998).

Another live-attenuated vaccination approach involves the use of Leishmania strains that are not pathogenic to humans. Vaccination with $L$. tarentolae, a lizard parasite, was shown to induce DC maturation, Th1 response, and protection against virulent $L$. donovani challenge (Breton et al., 2005). In addition, vaccination with $L$. tarentolae expressing A2 (amastigote-specific) antigen of L. donovani induced strong Th1 response leading to protection against L. donovani challenge (Mizbani et al., 2009). The use of nonpathogenic Leishmania parasite would most probably eliminate the fear of disease development following vaccination. However, many questions remain to be answered, such as how long nonvirulent parasites would persist in vaccinated host, the quality and durability of the primary and memory immune responses, and whether such immunity could cross protect against other Leishmania species.

\section{SUBUNIT VACCINES}

Subunit vaccines are attractive because they lack the ability to cause disease and are relatively cheap to produce and standardize. Several Leishmania protein antigens have been used as subunit vaccine candidates against leishmaniasis. Vaccination with Leish-111f, a recombinant polyprotein vaccine that contains thiol-specific antioxidant (TSA), L. major stress inducible protein 1 (LmST11) and L. major elongation initiation factor (LeIF) was shown to protect against both visceral and CL (Coler et al., 2007). Phases 1 and II clinical trials for Leish-111f vaccine have been completed and show that the vaccine is safe and immunogenic in both healthy and adult patients with mucocutaneous and CL (Llanos-Cuentas et al., 2010). This vaccine has also been used therapeutically in combination with sodium stilbogluconate for treatment of mucosal leishmaniasis (Llanos-Cuentas et al., 2010) and in combination with meglumine for the treatment of human CL (Nascimento et al., 2010). Interestingly, although a recent study suggested that the Leish-111f vaccine could also partially protect dogs against VL (Coler et al., 2007), it failed to induce any significant protection in vaccinated dogs in a well-controlled Phase III trial (Gradoni et al., 2005). More clinical studies are needed to determine the potential of using this vaccine to control human leishmaniasis. A more recent study showed that the polyprotein comprising of kinetoplastid membrane protein 11 (KMP11), Sterol 24-cmethyltransferase (SMT), A2, and cysteine proteinase B (CPB) 
given with monophosphoryl lipid A (MPL-SE) as adjuvant was able to protect mice against visceral and CL caused by L. infantum and L. major, respectively (Goto et al., 2011). It will be interesting to determine the clinical efficacy of this vaccine as a prophylactic or therapeutic vaccine in human or canine leishmaniasis.

A large effort has focused on Gp63, also known as leishmanolysin, which is a major surface protein on Leishmania promastigotes, because of its protease activity and role in virulence (Yao et al., 2003). One study showed that vaccination with recombinant gp63 expressed in E. coli failed to protect mice against virulent L. major challenge (Handman et al., 1990). In another report, BALB/c mice vaccinated with recombinant gp63 (rgp63) encapsulated in cationic liposome with CpG ODN as an adjuvant had significant reduction in parasite burden, lower IL-4 (Th2) production, and higher Th1 response compared to mice that received rgp63 alone or rgp63 plus CpG ODN following virulent L. major challenge (Jaafari et al., 2007). In a more recent study, vaccination with a DNA vaccine containing rgp63 from $L$. mexicana induced better protective immunity in BALB/c mice as evidenced by higher serum levels of parasite-specific IgG2a, smaller lesion size and more robust lytic activity of the CTL induced in the DNA vaccinated mice compared to those that received the empty vector (Rezvan et al., 2011). Paradoxically, vaccination with rgp63 conferred partial protection in Vervet monkeys (Olobo et al., 1995). More studies are required to further elucidate the potential of using gp63 as a subunit vaccine either alone or in combination with other antigens.

Other Leishmania proteins that have been targeted for vaccination include the Leishmania homolog for receptors of activated C kinase (LACK), a conserved antigen expressed in both promastigote and amastigote life stages (Mougneau et al., 1995; Gurunathan et al., 1998; Melby et al., 2001) and the highly immunogenic cathepsin L-like cysteine proteinases (Rafati et al., 2003; ZadehVakili et al., 2004). Recently a polyprotein vaccine made up of LACK, TSA, LbSTI, or LeIF was shown to protect mice against CL caused by $L$. major but failed to protect disease caused by $L$. braziliensis (Salay et al., 2007). This result is rather puzzling given that the vaccine consisted of components derived from antigens that are conserved across all Leishmania and hence should cross protect against different Leishmania species.

\section{DNA VACCINES}

DNA vaccines are capable of eliciting strong immune responses similar to those induced by protein antigens and this could be further enhanced and modulated by the inclusion of adjuvants or cytokines (Alarcon et al., 1999; Restifo et al., 2000). Since protection against leishmaniasis requires the induction of early Th1 response, DNA vaccination is a very attractive strategy because of the propensity of DNA vaccines to elicit strong cell-mediated immunity (Gurunathan et al., 1997, 2000a). In addition, DNA vaccines mimic the protective effects of live vaccines without the potential danger of disease development, they are relatively easy and cheap to produce and unlike protein or live-attenuated vaccines, does not require the maintenance of "cold chain" sequence (Gurunathan et al., 2000b). Several experimental studies have shown that DNA vaccines confer strong protection against cutaneous (Doroud et al., 2011a,b) and visceral (Fragaki et al., 2001; Tewary et al., 2004; Saldarriaga et al., 2006; Masih et al., 2011;
Mazumder et al., 2011) leishmaniases. However, although DNA vaccination is considered a promising technology, it still remains an experimental practice because no development of such vaccines for use in humans has been reported so far. In addition, the conflicting reports on the protective efficacy of this vaccination strategy add to the confusion in the field (Kedzierski et al., 2006). There are also genuine concerns about ethics, safety, and delivery systems, which collectively have hampered the application of this technology in humans. At present, DNA vaccination remains a very attractive experimental research area with possible benefits in human medicine.

\section{CONCLUDING REMARKS}

Vaccination is one of the most cost-effective methods for protection against infectious diseases. There is an in-depth understanding of the immunobiology of leishmaniasis and studies in this area of research have helped shed lights into the factors that regulate the induction, maintenance, and loss of cell-mediated immunity in infectious diseases. Therefore, it is very frustrating and disappointing that despite this enormous wealth of information, there is currently no generally and globally acceptable, effective, and efficacious vaccine against the disease in humans. The reasons for this failure are many, but primarily related to the obvious differences between mouse and human immune systems. In addition, the use of different vaccination protocols (nature of adjuvants, frequency of vaccination, and/or boost, time before challenge) and arbitrary markers or correlates of protection in murine studies have complicated the situation (Okwor and Uzonna, 2009). Researchers tend to select vaccination protocols that most likely will yield desirable results in mice studies, which are unrealistic in clinical settings and/or "real world" environment. Therefore, it is important for researchers in this field to set standards for vaccination studies, such as the time from immunization to challenge and the minimum duration of immunity before any experimental vaccine and/or vaccination protocol is deemed protective. In addition, most of the vaccination studies (particularly CL) utilize BALB/c mice, which do not mimic the clinical disease in humans. The CL in the C57BL/6 mice more closely resembles the human disease and hence it is imperative that vaccination studies be conducted in this strain of mice.

It is generally accepted that immunity in leishmaniasis is dependent on persistence of a small number of parasites at the primary site of infection (infection-induced resistance). However, whether live replicating parasites or just persistent antigen is required to maintain immunity is not very clear. Studies with genetically modified Leishmania parasites such $d h f r$-ts that are naturally cleared by the host after infection will be helpful in elucidating the role of live replicating parasites in the maintenance of anti-Leishmania immunity. Persistent antigens are believed to be important for the maintenance of effector memory-like $\mathrm{T}$ cells that mediate rapid anti-Leishmania immunity (Zaph et al., 2004; Liu and Uzonna, 2010; Okwor et al., 2010). Therefore, an ideal anti-Leishmania vaccine must maintain constant turnover of Leishmania-specific memory cells in vaccinated hosts, akin to what is obtained in persistently infected mice that retain infectioninduced resistance (Figures 1A,B). This could be achieved by two mechanisms: strategic booster immunizations or vaccination with live-attenuated parasites (such as $l p g 2-L$. major) that 


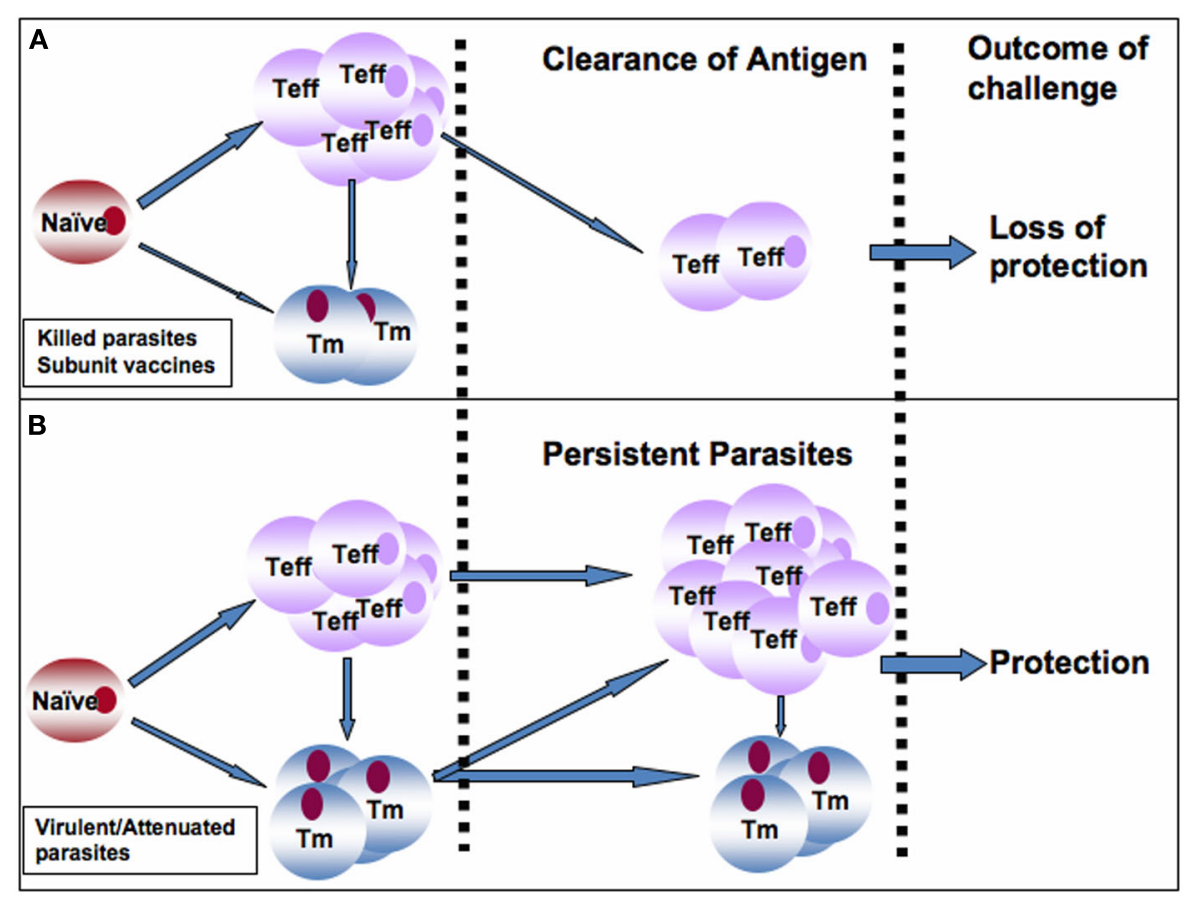

FIGURE 1 | Proposed model to explain the superior protective immunity induced by infection or vaccination with live-attenuated live parasites over those induced by killed parasites and subunit vaccines. (A) Following vaccination with killed or subunit vaccines, a robust effector $T$ cells (Teff) are generated from naïve Leishmania-specific T cells at the expense of memory $T$ (Tm) cells. It is plausible that some Teff cells could also convert into Tm cells. In the absence of persistence antigen (as seen following antigen clearance), the Teff cells are rapidly depleted leading to loss of immunity and susceptibility to secondary virulent challenge. (B) In contrast, infection with virulent parasites or vaccination with live-attenuated or genetically modified parasites leads to generation of robust and balanced Teff and Tm cells, infection-induced immunity, and persistence of low number of parasites at the infection site and its draining lymph node. Persistent parasites promote constant generation and maintenance of Teff and Tm cells in the draining lymph node leading to maintenance of immunity and protection against secondary virulent challenges. This would eliminate the need for frequent booster immunizations.

persist indefinitely at the primary infection site and its draining lymph nodes. We favor vaccination strategies that lead to maintenance of low levels of parasite antigens at the site of inoculation, which would promote constant generation and maintenance of protective effector and memory cells (Figure 1B). Such a strategy would generate infection-induced resistance and therefore eliminate the need for frequent booster immunizations (Figure 1B). In this regard, we believe that attenuated parasites generated by targeted deletion of specific virulent genes (such as lpg2-) are ideal vaccine candidates because they meet these requirements: persistence without pathology and induction of protection against virulent challenge. Thus, lpg2- parasites could overcome the side effects associated with leishmanization while providing immunity comparable to virulent parasites (Liu et al submitted). Although we recently showed that it is possible to maintain Leishmaniaspecific memory cells (and hence immunity) in the absence of live replicating parasites by repeated inoculation of killed parasites (Okwor et al., 2010), however this vaccination protocol may not be feasible in humans. Thus, more studies are required to optimize this vaccination protocol and to determine how long

\section{REFERENCES}

Aebischer, T., Moody, S. F., and Handman, E. (1993). Persistence of virulent Leishmania major in murine cutaneous leishmaniasis: a possible hazard for the host. Infect. Immun. 61, 220-226.

these cells will survive in vivo and also protect mice against virulent challenge. The use of nanoparticles as well as other slow release antigen delivery systems could help enhance durability of killed parasite and subunit vaccines. Currently, only few studies are looking into the use of nanoparticles as a vaccination strategy in leishmaniasis. Such studies are required to fully characterize the role of nanoparticles and similar technologies as vaccine strategies in leishmaniasis. In addition, there is need for increased use of bioinformatics and proteomics to identify new immune-dominant antigens and peptides that will be used as anti-Leishmania vaccine candidates.

\section{ACKNOWLEDGMENTS}

We thank members of Parasite Vaccines Development Laboratory for their insightful comments and constructive criticisms. This work was supported by grants from the Canadian Institutes of Health Research (CIHR) and Manitoba Health Research Council (MHRC). IO is supported by the CIHR Doctoral Award and CIHR International Infectious Disease and Global Health Training Program.

Afonso, L. C., Scharton, T. M., Vieira, L. Q., Wysocka, M., Trinchieri, G., and Scott, P. (1994). The adjuvant effect of interleukin-12 in a vaccine against Leishmania major. Science 263, 235-237.

Aga, E., Katschinski, D. M., van Zandbergen, G., Laufs, H., Hansen, B., 
Müller, K., Solbach, W., and Laskay, T. (2002). Inhibition of the spontaneous apoptosis of neutrophil granulocytes by the intracellular parasite Leishmania major. J. Immunol. 169, 898-905.

Akilov, O. E., Ustyugova, I. V., Zhi, L., Hasan, T., and Wu, M. X. (2009). Enhanced susceptibility to Leishmania infection in resistant mice in the absence of immediate early response gene X-1. J. Immunol. 183, 7994-8003.

Alarcon, J. B., Waine, G. W., and McManus, D. P. (1999). DNA vaccines: technology and application as anti-parasite and anti-microbial agents. Adv. Parasitol. 42, 343-410.

Alexander, J., Brombacher, F., McGachy, H. A., McKenzie, A. N., Walker, W., and Carter, K. C. (2002). An essential role for IL-13 in maintaining a non-healing response following Leishmania mexicana infection. Eur. J. Immunol. 32, 2923-2933.

Alexander, J., Coombs, G. H., and Mottram, J. C. (1998). Leishmania mexicana cysteine proteinasedeficient mutants have attenuated virulence for mice and potentiate a Th1 response. J. Immunol. 161, 6794-6801.

Amaral, V. F., Teva, A., Oliveira-Neto, M. P., Silva, A. J., Pereira, M. S., Cupolillo, E., Porrozzi, R., Coutinho, S. G., Pirmez, C., Beverley, S. M., and Grimaldi G, J. r. (2002). Study of the safety, immunogenicity and efficacy of attenuated and killed Leishmania (Leishmania) major vaccines in a rhesus monkey (Macaca mulatta) model of the human disease. Mem. Inst. Oswaldo Cruz 97, 1041-1048.

Anderson, C. F., Mendez, S., and Sacks, D. L. (2005). Nonhealing infection despite Th1 polarization produced by a strain of Leishmania major in C57BL/6 mice. J. Immunol. 174, 2934-2941.

Anderson, C. F., Oukka, M., Kuchroo, V. J., and Sacks, D. (2007). CD4(+)CD25(-)Foxp3(-) Th1 cells are the source of IL-10mediated immune suppression in chronic cutaneous leishmaniasis. $J$. Exp. Med. 204, 285-297.

Anderson, C. F., Stumhofer, J. S., Hunter, C. A., and Sacks, D. (2009). IL27 regulates IL-10 and IL-17 from CD4+ cells in nonhealing Leishmania major infection. J. Immunol. 183 , 4619-4627.

Armijos, R. X., Weigel, M. M., Calvopina, M., Hidalgo, A., Cevallos, W., and Correa, J. (2004). Safety, immunogenecity, and efficacy of an autoclaved Leishmania amazonensis vaccine plus BCG adjuvant against
New World cutaneous leishmaniasis. Vaccine 22, 1320-1326.

Bailey, M. S. (2011). Cutaneous leishmaniasis in British troops following jungle training in Belize. Travel Med. Infect Dis. 9, 253-254.

Belkaid, Y., Piccirillo, C. A., Mendez, S., Shevach, E. M., and Sacks, D. L. (2002). CD4+CD25+ regulatory T cells control Leishmania major persistence and immunity. Nature 420, 502-507.

Belosevic, M., Finbloom, D. S., Van Der Meide, P. H., Slayter, M. V., and Nacy, C. A. (1989). Administration of monoclonal anti-IFNgamma antibodies in vivo abrogates natural resistance of $\mathrm{C} 3 \mathrm{H} / \mathrm{HeN}$ mice to infection with Leishmania major. J. Immunol. 143, 266-274.

Birnbaum, R., and Craft, N. (2011). Innate immunity and Leishmania vaccination strategies. Dermatol. Clin. 29, 89-102.

Boaventura, V. S., Santos, C. S., Cardoso, C. R., de Andrade, J., Dos Santos, W. L., Clarêncio, J., Silva, J. S., Borges, V. M., Barral-Netto, M., Brodskyn, C. I., and Barral, A. (2010). Human mucosal leishmaniasis: neutrophils infiltrate areas of tissue damage that express high levels of Th17-related cytokines. Eur. J. Immunol. 40, 2830-2836.

Bourreau, E., Ronet, C., Darcissac, E., Lise, M. C., Sainte Marie, D., Clity, E., Tacchini-Cottier, F., Couppie, P., and Launois, P. (2009). Intralesional regulatory T-cell suppressive function during human acute and chronic cutaneous leishmaniasis due to Leishmania guyanensis. Infect. Immun. 77, 1465-1474.

Breton, M., Tremblay, M. J., Ouellette, M., and Papadopoulou, B. (2005). Live nonpathogenic parasitic vector as a candidate vaccine against visceral leishmaniasis. Infect. Immun. 73, 6372-6382.

Brodskyn, C., Beverley, S. M., and Titus, R. G. (2000). Virulent or avirulent (dhfr-ts-) Leishmania major elicit predominantly a type-1 cytokine response by human cells in vitro. Clin. Exp. Immunol. 119, 299-304.

Brombacher, F. (2000). The role of interleukin-13 in infectious diseases and allergy. Bioessays 22, 646-656.

Brombacher, F. (ed.). (2003). Interleukin-13. Georgetown, TX: Landes Bioscience.

Campanelli, A. P., Roselino, A. M., Cavassani, K. A., Pereira, M. S., Mortara, R. A., Brodskyn, C. I., Goncalves, H. S., Belkaid, Y., BarralNetto, M., Barral, A., and Silva, J. S. (2006). CD4+CD25+ T cells in skin lesions of patients with cutaneous leishmaniasis exhibit phenotypic and functional characteristics of natural regulatory T cells. J. Infect. Dis. 193, 1313-1322.

Chang, S. H., Reynolds, J. M., Pappu, B. P., Chen, G., Martinez, G. J., and Dong, C. (2011). Interleukin-17C promotes Th17 cell responses and autoimmune disease via interleukin-17 receptor E. Immunity $35,611-621$.

Chappuis, J., Simoens, C., Smets, D., Duttmann, R., and Mendes da Costa, P. (2007). Spontaneous rupture of the spleen in relation to a nonHodgkin lymphoma. Acta Chir. Belg. 107:446-448.

Chatelain, R., Mauze, S., and Coffman, R. L. (1999). Experimental Leishmania major infection in mice: role of IL-10. Parasite Immunol. 21, 211-218.

Coler, R. N., Goto, Y., Bogatzki, L., Raman, V., and Reed, S. G. (2007). Leish-111f, a recombinant polyprotein vaccine that protects against visceral Leishmaniasis by elicitation of CD4+ T cells. Infect. Immun. 75 , 4648-4654.

Daneshvar, H., Burchmore, R., Hagan, P., and Phillips, R. S. (2009). Leishmania major $\mathrm{H}$-line attenuated under pressure of gentamicin, induces a Thl response which protects susceptible BALB/c mice against infection with virulent Leish mania major. Parasitology 136 1243-1250.

Davoudi, N., Tate, C. A., Warburton, C., Murray, A., Mahboudi, F., and McMaster, W. R. (2005). Development of a recombinant Leishmania major strain sensitive to ganciclovir and 5-fluorocytosine for use as a live vaccine challenge in clinical trials. Vaccine 23, 1170-1177.

Desjeux, P. (1996). Leishmaniasis. Public health aspects and control. Clin. Dermatol. 14, 417-423.

Di Santo, E., Meazza, C., Sironi, M., Fruscella, P., Mantovani, A., Sipe, J. D., and Ghezzi, P. (1997). IL-13 inhibits TNF production but potentiates that of IL-6 in vivo and ex vivo in mice. J. Immunol. 159, 379-382.

Doroud, D., Zahedifard, F., Vatanara, A., Taslimi, Y., Vahabpour, R., Torkashvand, F., Vaziri, B., Rouholamini Najafabadi, A., and Rafati, S. (2011a). C-terminal domain deletion enhances the protective activity of cpa/cpb loaded solid lipid nanoparticles against Leishmania major in BALB/c mice. PLoS Negl. Trop. Dis. 5, e1236. doi:10.1371/journal.pntd.0001236

Doroud, D., Zahedifard, F., Vatanara, A., Najafabadi, A. R., Taslimi, Y.,
Vahabpour, R., Torkashvand, F., Vaziri, B., and Rafati, S. (2011b). Delivery of a cocktail DNA vaccine encoding cysteine proteinases type I, II and III with solid lipid nanoparticles potentiate protective immunity against Leishmania major infection. J. Control. Release 153, 154-162.

Doyle, A. G., Herbein, G., Montaner, L. J., Minty, A. J., Caput, D., Ferrara, P., and Gordon, S. (1994). Interleukin13 alters the activation state of murine macrophages in vitro: comparison with interleukin-4 and interferon-gamma. Eur. J. Immunol. 24, 1441-1445.

Elhay, M., Kelleher, M., Bacic, A., McConville, M. J., Tolson, D. L., Pearson, T. W., and Handman, E. (1990). Lipophosphoglycan expression and virulence in ricinresistant variants of Leishmania major. Mol. Biochem. Parasitol. 40, 255-267.

Farrell, J. P., and Kirkpatrick, C. E. (1987). Experimental cutaneous leishmaniasis. II. A possible role for prostaglandins in exacerbation of disease in Leishmania majorinfected $\mathrm{BALB} / \mathrm{c}$ mice. J. Immunol. 138, 902-907.

Fiorentino, D. F., Zlotnik, A., Vieira, P., Mosmann, T. R., Howard, M., Moore, K. W., and O'Garra, A. (1991). IL-10 acts on the antigenpresenting cell to inhibit cytokine production by Th1 cells. J. Immunol. 146, 3444-3451.

Fragaki, K., Suffia, I., Ferrua, B., Rousseau, D., Le Fichoux, Y., and Kubar, J. (2001). Immunisation with DNA encoding Leishmania infantum protein papLe 22 decreases the frequency of parasitemic episodes in infected hamsters. Vaccine 19, 1701-1709.

Gicheru, M. M., Olobo, J. O., Anjili, C. O., Orago, A. S., Modabber, F., and Scott, P. (2001). Vervet monkeys vaccinated with killed Leishmania major parasites and interleukin-12 develop a type 1 immune response but are not protected against challenge infection. Infect. Immun. 69, 245-251.

Goto, Y., Bhatia, A., Raman, V. S., Liang, H., Mohamath, R., Picone, A. F., Vidal, S. E., Vedvick, T. S., Howard, R. F., and Reed, S. G. (2011). KSAC, the first defined polyprotein vaccine candidate for visceral leishmaniasis. Clin. Vaccine Immunol. 18, 1118-1124

Gradoni, L., Foglia Manzillo, V., Pagano, A., Piantedosi, D., De Luna, R., Gramiccia, M., Scalone, A., Di Muccio, T., and Oliva, G. (2005). Failure of a multi-subunit recombinant 
leishmanial vaccine (MML) to protect dogs from Leishmania infantum infection and to prevent disease progression in infected animals. Vaccine 23, 5245-5251.

Greenblatt, C. L. (1980). The present and future of vaccination for cutaneous leishmaniasis. Prog. Clin. Biol. Res. 47, 259-285.

Gurunathan, S., Prussin, C., Sacks, D. L., and Seder, R. A. (1998). Vaccine requirements for sustained cellular immunity to an intracellular parasitic infection. Nat. Med. 4, 1409-1415.

Gurunathan, S., Sacks, D. L., Brown, D. R., Reiner, S. L., Charest, H., Glaichenhaus, N., and Seder, R. A. (1997). Vaccination with DNA encoding the immunodominant LACK parasite antigen confers protective immunity to mice infected with Leishmania major. J. Exp. Med. 186, 1137-1147.

Gurunathan, S., Wu, C. Y., Freidag, B. L., and Seder, R. A. (2000a). DNA vaccines: a key for inducing longterm cellular immunity. Curr. Opin. Immunol. 12, 442-447.

Gurunathan, S., Klinman, D. M., and Seder, R. A. (2000b). DNA vaccines: immunology, application, and optimization*. Annu. Rev. Immunol. $18,927-974$

Handman, E. (2001). Leishmaniasis: current status of vaccine development. Clin. Microbiol. Rev. 14, 229-243.

Handman, E., Button, L. L., and McMaster, R. W. (1990). Leishmania major: production of recombinant gp63, its antigenicity and immunogenicity in mice. Exp. Parasitol. 70, 427-435.

Heinzel, F. P., Rerko, R. M., Ahmed, F., and Pearlman, E. (1995). Endogenous IL-12 is required for control of Th2 cytokine responses capable of exacerbating leishmaniasis in normally resistant mice. J. Immunol. $155,730-739$.

Heinzel, F. P., Sadick, M. D., Holaday, B. J., Coffman, R. L., and Locksley, R. M. (1989). Reciprocal expression of interferon gamma or interleukin 4 during the resolution or progression of murine leishmaniasis. Evidence for expansion of distinct helper $\mathrm{T}$ cell subsets. J. Exp. Med. 169, 59-72.

Heinzel, F. P., Schoenhaut, D. S., Rerko, R. M., Rosser, L. E., and Gately, M. K. (1993). Recombinant interleukin 12 cures mice infected with Leishmania major. J. Exp. Med. 177, 1505-1509.

Himmelrich, H., Launois, P., Maillard, I., Biedermann, T., Tacchini-Cottier, F., Locksley, R. M., Röcken, M., and Louis, J. A. (2000). In BALB/c mice, IL-4 production during the initial phase of infection with Leishmania major is necessary and sufficient to instruct Th2 cell development resulting in progressive disease. $J$. Immunol. 164, 4819-4825.

Himmelrich, H., Parra-Lopez, C., Tacchini-Cottier, F., Louis, J. A., and Launois, P. (1998). The IL-4 rapidly produced in $\mathrm{BALB} / \mathrm{c}$ mice after infection with Leishmania major down-regulates IL-12 receptor beta 2-chain expression on $\mathrm{CD} 4+\mathrm{T}$ cells resulting in a state of unresponsiveness to IL-12. J. Immunol. 161, 6156-6163.

Holaday, B. J., Sadick, M. D., Wang, Z. E., Reiner, S. L., Heinzel, F. P., Parslow, T. G., and Locksley, R. M. (1991). Reconstitution of Leishmania immunity in severe combined immunodeficient mice using Th1and Th2-like cell lines. J. Immunol. 147, 1653-1658.

Huber, M., Timms, E., Mak, T. W., Röllinghoff, M., and Lohoff, M. (1998). Effective and long-lasting immunity against the parasite Leishmania major in CD8-deficient mice. Infect. Immun. 66, 3968-3970.

Jaafari, M. R., Badiee, A., Khamesipour, A., Samiei, A., Soroush, D., Kheiri, M. T., Barkhordari, F., McMaster, W. R., and Mahboudi, F. (2007). The role of CpG ODN in enhancement of immune response and protection in $\mathrm{BALB} / \mathrm{c}$ mice immunized with recombinant major surface glycoprotein of Leishmania (rgp63) encapsulated in cationic liposome. Vaccine 25, 6107-6117.

John, B., and Hunter, C. A. (2008). Immunology. Neutrophil soldiers or Trojan horses? Science 321, 917-918.

Jones, D. E., Ackermann, M. R., Wille, U., Hunter, C. A., and Scott, P. (2002). Early enhanced Th1 response after Leishmania amazonensis infection of C57BL/6 interleukin-10-deficient mice does not lead to resolution of infection. Infect. Immun. 70, 2151-2158.

Kane, M. M., and Mosser, D. M. (2000). Leishmania parasites and their ploys to disrupt macrophage activation. Curr. Opin. Hematol. 7 , 26-31.

Kedzierski, L., Curtis, J. M., Doherty, P. C., Handman, E., and Kedzierska, K. (2008). Decreased IL-10 and IL-13 production and increased CD44hi T cell recruitment contribute to Leishmania major immunity induced by non-persistent parasites. Eur. J. Immunol. 38, 3090-3100.

Kedzierski, L., Zhu, Y., and Handman, E. (2006). Leishmania vaccines: progress and problems. Parasitology 133(Suppl.), S87-S112.
Khalil, E. A., El Hassan, A. M., Zijlstra, E. E., Mukhtar, M. M., Ghalib, H. W., Musa, B., Ibrahim, M. E., Kamil, A. A., Elsheikh, M., Babiker, A., and Modabber, F. (2000). Autoclaved Leishmania major vaccine for prevention of visceral leishmaniasis: a randomised, double-blind, BCGcontrolled trial in Sudan. Lancet 356, 1565-1569.

Khamesipour, A., Dowlati, Y., Asilian, A., Hashemi-Fesharki, R., Javadi, A., Noazin, S., and Modabber, F (2005). Leishmanization: use of an old method for evaluation of candidate vaccines against leishmaniasis. Vaccine 23, 3642-3648.

Korbel, D. S., Finney, O. C., and Riley, E. M. (2004). Natural killer cells and innate immunity to protozoan pathogens. Int. J. Parasitol. 34 1517-1528.

Laabs, E. M., Wu, W., and Mendez, S. (2009). Vaccination with live Leishmania major and CpG DNA promotes interleukin-2 production by dermal dendritic cells and NK cell activation. Clin. Vaccine Immunol. 16, 1601-1606.

Lages, C. S., Suffia, I., Velilla, P. A., Huang, B., Warshaw, G., Hildeman, D. A., Belkaid, Y., and Chougnet, C. (2008). Functional regulatory $\mathrm{T}$ cells accumulate in aged hosts and promote chronic infectious disease reactivation. J. Immunol. 181, 1835-1848.

Laurenti, M. D., Gidlund, M., Ura, D. M., Sinhorini, I. L., Corbett, C. E., and Goto, H. (1999). The role of natural killer cells in the early period of infection in murine cutaneous leishmaniasis. Braz. J. Med. Biol. Res. 32 323-325.

Leon, B., Lopez-Bravo, M., and Ardavin, C. (2007). Monocyte-derived dendritic cells formed at the infection site control the induction of protective $\mathrm{T}$ helper 1 responses against Leishmania. Immunity 26 519-531.

Lerner, E. A., and Shoemaker, C. B. (1992). Maxadilan. Cloning and functional expression of the gene encoding this potent vasodilator peptide. J. Biol. Chem. 267, 1062-1066.

Liese, J., Schleicher, U., and Bogdan, C. (2008). The innate immune response against Leishmania parasites. Immunobiology 213, 377-387.

Liew, F. Y., Li, Y., and Millott, S. (1990a). Tumour necrosis factor (TNF-alpha) in leishmaniasis. II. TNF-alpha-induced macrophage leishmanicidal activity is mediated by nitric oxide from L-arginine. Immunology 71, 556-559.
Liew, F. Y., Parkinson, C., Millott, S., Severn, A., and Carrier, M. (1990b). Tumour necrosis factor (TNF alpha) in leishmaniasis. I. TNF alpha mediates host protection against cutaneous leishmaniasis. Immunology 69, 570-573.

Lira, R., Sundar, S., Makharia, A., Kenney, R., Gam, A., Saraiva, E., and Sacks, D. (1999). Evidence that the high incidence of treatment failures in Indian kala-azar is due to the emergence of antimony-resistant strains of Leishmania donovani. J. Infect. Dis. 180, 564-567.

Liu, D., and Uzonna, J. E. (2010). The p110 delta isoform of phosphatidylinositol 3-kinase controls the quality of secondary anti-Leishmania immunity by regulating expansion and effector function of memory $\mathrm{T}$ cell subsets. J. Immunol. 184 3098-3105.

Liu, D., Zhang, T., Marshall, A. J., Okkenhaug, K., Vanhaesebroeck, B., and Uzonna, J. E. (2009). The p110delta isoform of phosphatidylinositol 3-kinase controls susceptibility to Leishmania major by regulating expansion and tissue homing of regulatory T cells. J. Immunol. 183, 1921-1933.

Llanos-Cuentas, A., Calderón, W., Cruz, M., Ashman, J. A., Alves, F. P., Coler, R. N., Bogatzki, L. Y., Bertholet, S., Laughlin, E. M., Kahn, S. J., Beckmann, A. M., Cowgill, K. D., Reed, S. G., and Piazza, F. M. (2010). A clinical trial to evaluate the safety and immunogenicity of the LEISH-F1+MPL-SE vaccine when used in combination with sodium stibogluconate for the treatment of mucosal leishmaniasis. Vaccine 28, 7427-7435.

Locksley, R. M., Wakil, A. E., Corry, D. B., Pingel, S., Bix, M., and Fowell, D. J. (1995). The development of effector $\mathrm{T}$ cell subsets in murine Leishmania major infection. Ciba Found. Symp. 195, 110-117; discussion 117-122.

Lopez Kostka, S., Dinges, S., Griewank, K., Iwakura, Y., Udey, M. C., and von Stebut, E. (2009). IL-17 promotes progression of cutaneous leishmaniasis in susceptible mice. J. Immunol. 182, 3039-3046.

Louis, J. A., Conceiçao-Silva, F., Himmelrich, H., Tacchini-Cottier, F., and Launois, P. (1998a). Anti-leishmania effector functions of CD4+ Th1 cells and early events instructing Th2 cell development and susceptibility to Leishmania major in BALB/c mice. Adv. Exp. Med. Biol. 452, 53-60.

Louis, J., Himmelrich, H., Parra-Lopez, C., Tacchini-Cottier, F., and Launois, 
P. (1998b). Regulation of protective immunity against Leishmania major in mice. Curr. Opin. Immunol. 10, 459-464.

Makala, L. H., Baban, B., Lemos, H., El-Awady, A. R., Chandler, P. R., Hou, D. Y., Munn, D. H., and Mellor, A. L. (2011). Leishmania major attenuates host immunity by stimulating local indoleamine 2,3dioxygenase expression. J. Infect. Dis. 203, 715-725.

Masih, S., Arora, S. K., and Vasishta, R. K. (2011). Efficacy of Leishmania donovani ribosomal $\mathrm{P} 1$ gene as DNA vaccine in experimental visceral leishmaniasis. Exp. Parasitol. 129, 55-64.

Matthews, D. J., Emson, C. L., McKenzie, G. J., Jolin, H. E., Blackwell, J. M., and McKenzie, A. N. (2000). IL-13 is a susceptibility factor for Leishmania major infection. J. Immunol. 164, 1458-1462.

Mazumder, S., Maji, M., Das, A., and Ali, N. (2011). Potency, efficacy and durability of DNA/DNA, DNA/protein and protein/protein based vaccination using gp63 against Leishmania donovani in BALB/c mice. PLoS ONE 6, e14644. doi:10.1371/journal.pone.0014644

Melby, P. C., Yang, J., Zhao, W., Perez, L. E., and Cheng, J. (2001). Leishmania donovani $\mathrm{p} 36$ (LACK) DNA vaccine is highly immunogenic but not protective against experimental visceral leishmaniasis. Infect. Immun. 69, 4719-4725.

Mendez, S., Reckling, S. K., Piccirillo, C. A., Sacks, D., and Belkaid, Y. (2004). Role for CD4(+) CD25(+) regulatory $\mathrm{T}$ cells in reactivation of persistent leishmaniasis and control of concomitant immunity. J. Exp. Med. 200, 201-210.

Mendez, S., Tabbara, K., Belkaid, Y., Bertholet, S., Verthelyi, D., Klinman, D., Seder, R. A., and Sacks, D. L. (2003). Coinjection with CpG-containing immunostimulatory oligodeoxynucleotides reduces the pathogenicity of a live vaccine against cutaneous Leishmaniasis but maintains its potency and durability. Infect. Immun. 71, 5121-5129.

Milano, S., Arcoleo, F., Dieli, M., D’Agostino, R., De Nucci, G., D’Agostino, P., and Cillari, E. (1996). Ex vivo evidence for PGE2 and LTB4 involvement in cutaneous leishmaniasis: relation with infection status and cytokine production. Parasitology 112(Pt 1), 13-19.

Mizbani, A., Taheri, T., Zahedifard, F., Taslimi, Y., Azizi, H., Azadmanesh, K., Papadopoulou, B., and Rafati, S. (2009). Recombinant Leishmania tarentolae expressing the A2 virulence gene as a novel candidate vaccine against visceral leishmaniasis. Vaccine 28, 53-62.

Mohrs, M., Ledermann, B., Köhler, G., Dorfmüller, A., Gessner, A., and Brombacher, F. (1999). Differences between IL-4- and IL-4 receptor alpha-deficient mice in chronic leishmaniasis reveal a protective role for IL-13 receptor signaling. J. Immunol. 162, 7302-7308.

Momeni, A. Z., and Aminjavaheri, M. (1995). Treatment of recurrent cutaneous Leishmaniasis. Int. J. Dermatol. 34, 129-133.

Momeni, A. Z., Jalayer, T., Emamjomeh, M., Khamesipour, A., Zicker, F., Ghassemi, R. L., Dowlati, Y., Sharifi, I., Aminjavaheri, M., Shafiei, A., Alimohammadian, M. H., HashemiFesharki, R., Nasseri, K., Godal, T., Smith, P. G., and Modabber, F. (1999). A randomised, doubleblind, controlled trial of a killed L. major vaccine plus BCG against zoonotic cutaneous leishmaniasis in Iran. Vaccine 17, 466-472.

Mosmann, T. R., Cherwinski, H., Bond, M. W., Giedlin, M. A., and Coffman, R. L. (1986). Two types of murine helper $\mathrm{T}$ cell clone. I. Definition according to profiles of lymphokine activities and secreted proteins. J. Immunol. 136, 2348-2357.

Mosmann, T. R., and Moore, K. W. (1991). The role of IL-10 in crossregulation of $\mathrm{TH} 1$ and $\mathrm{TH} 2$ responses. Immunol. Today 12, A49-A53.

Mou, Z., Jia, P., Kuriakose, S., Khadem, F., and Uzonna, J. E. (2010). Interleukin-17-mediated control of parasitemia in experimental Trypanosoma congolense infection in mice. Infect. Immun. 78, 5271-5279.

Mougneau, E., Altare, F., Wakil, A. E., Zheng, S., Coppola, T., Wang, Z. E., Waldmann, R., Locksley, R. M., and Glaichenhaus, N. (1995). Expression cloning of a protective Leishmania antigen. Science 268, 563-566.

Mougneau, E., Bihl, F., and Glaichenhaus, N. (2011). Cell biology and immunology of Leishmania. Immunol. Rev. 240, 286-296.

Mueller, T. D., Zhang, J. L., Sebald, W., and Duschl, A. (2002). Structure, binding, and antagonists in the IL-4/IL-13 receptor system. Biochim. Biophys. Acta 1592, 237-250.

Muyombwe, A., Olivier, M., Ouellette, M., and Papadopoulou, B. (1997). Selective killing of Leishmania amastigotes expressing a thymidine kinase suicide gene. Exp. Parasitol. 85, 35-42.

Nascimento, E., Fernandes, D. F., Vieira, E. P., Campos-Neto, A., Ashman,
J. A., Alves, F. P., Coler, R. N., Bogatzki, L. Y., Kahn, S. J., Beckmann, A. M., Pine, S. O., Cowgill, K. D., Reed, S. G., and Piazza, F. M. (2010). A clinical trial to evaluate the safety and immunogenicity of the LEISH-F1+MPL-SE vaccine when used in combination with meglumine antimoniate for the treatment of cutaneous leishmaniasis. Vaccine 28, 6581-6587.

Nashleanas, M., and Scott, P. (2000). Activated T cells induce macrophages to produce $\mathrm{NO}$ and control Leishmania major in the absence of tumor necrosis factor receptor p55. Infect. Immun. 68, 1428-1434.

Noben-Trauth, N., and Kropf, P. (1996). Muller I. Susceptibility to Leishmania major infection in interleukin-4deficient mice. Science 271, 987-990.

Noben-Trauth, N., Lira, R., Nagase, H., Paul, W. E., and Sacks, D. L. (2003). The relative contribution of IL-4 receptor signaling and IL-10 to susceptibility to Leishmania major. J. Immunol. 170, 5152-5158.

Noben-Trauth, N., Paul, W. E., and Sacks, D. L. (1999). IL-4- and IL4 receptor-deficient $\mathrm{BALB} / \mathrm{c}$ mice reveal differences in susceptibility to Leishmania major parasite substrains. J. Immunol. 162, 6132-6140.

Novais, F. O., Santiago, R. C., Báfica, A. Khouri, R., Afonso, L., Borges, V. M., Brodskyn, C., Barral-Netto, M., Barral, A., and de Oliveira, C. I. (2009). Neutrophils and macrophages cooperate in host resistance against Leishmania braziliensis infection. J. Immunol. 183, 8088-8098.

Nylen, S., Maasho, K., Söderstrom, K., Ilg, T., and Akuffo, H. (2003). Live Leishmania promastigotes can directly activate primary human natural killer cells to produce interferon-gamma. Clin. Exp. Immunol. 131, 457-467.

Okwor, I., Kuriakose, S., and Uzonna, J. (2010). Repeated inoculation of killed Leishmania major induces durable immune response that protects mice against virulent challenge. Vaccine 28, 5451-5457.

Okwor, I., Liu, D., Beverley, S. M. and Uzonna, J. E. (2009). Inoculation of killed Leishmania major into immune mice rapidly disrupts immunity to a secondary challenge via IL-10-mediated process. Proc. Natl. Acad. Sci. U.S.A. 106, 13951-13956.

Okwor, I., and Uzonna, J. (2008). Persistent parasites and immunologic memory in cutaneous leishmaniasis: implications for vaccine designs and vaccination strategies. Immunol. Res. 41, 123-136.

Okwor, I., and Uzonna, J. (2009). Vaccines and vaccination strategies against human cutaneous leishmaniasis. Hum. Vaccin. 5, 291-301.

Olobo, J. O., Anjili, C. O., Gicheru, M. M., Mbati, P. A., Kariuki, T. M., Githure, J. I., Koech, D. K., and McMaster, W. R. (1995). Vaccination of vervet monkeys against cutaneous Leishmaniosis using recombinant Leishmania "major surface glycoprotein” (gp63). Vet. Parasitol. 60, 199-212.

Padigel, U. M., Alexander, J., and Farrell, J. P. (2003). The role of interleukin10 in susceptibility of BALB/c mice to infection with Leishmania mexicana and Leishmania amazonensis. J. Immunol. 171, 3705-3710.

Palatnik-de-Sousa, C. B. (2008). Vaccines for leishmaniasis in the fore coming 25 years. Vaccine 26, 1709-1724.

Paludan, S. R., Lovmand, J., EllermannEriksen, S., and Mogensen, S. C. (1997). Effect of IL-4 and IL13 on IFN-gamma-induced production of nitric oxide in mouse macrophages infected with herpes simplex virus type 2. FEBS Lett. 414, 61-64.

Park, A. Y., Hondowicz, B. D., and Scott, P. (2000). IL-12 is required to maintain a Th1 response during Leishmania major infection. J. Immunol. 165 , 896-902.

Peters, N. C., Egen, J. G., Secundino, N., Debrabant, A., Kimblin, N., Kamhawi, S., Lawyer, P., Fay, M. P., Germain, R. N., and Sacks, D. (2008). In vivo imaging reveals an essential role for neutrophils in leishmaniasis transmitted by sand flies. Science 321, 970-974.

Pitta, M. G., Romano, A., Cabantous, S., Henri, S., Hammad, A., Kouriba, B., Argiro, L., el Kheir, M., Bucheton, B., Mary, C., El-Safi, S. H., and Dessein, A. (2009). IL-17 and IL-22 are associated with protection against human kala azar caused by Leishmania donovani. J. Clin. Invest. 119, 2379-2387.

Racoosin, E. L., and Beverley, S. M. (1997). Leishmania major: promastigotes induce expression of a subset of chemokine genes in murine macrophages. Exp. Parasitol. 85, 283-295.

Rafati, S., Nakhaee, A., Taheri, T., Ghashghaii, A., Salmanian, A. H., Jimenez, M., Mohebali, M., Masina, S., and Fasel, N. (2003). Expression of cysteine proteinase type I and II of Leishmania infantum and their 
recognition by sera during canine and human visceral leishmaniasis. Exp. Parasitol. 103, 143-151.

Reiner, S. L., and Locksley, R. M. (1995). The regulation of immunity to Leishmania major. Annu. Rev. Immunol. 13, 151-177.

Reinhard, K., Huber, M., Wostl, C., Hellhund, A., Toboldt, A., Abass, E., Casper, B., Joeris, T., Herr, C., Bals, R., Steinhoff, U., Lohoff, M., and Visekruna, A. (2011). cRel promotes type 1 and type 17 immune responses during Leishmania major infection. Eur. J. Immunol. 41, 1388-1398.

Reithinger, R., Dujardin, J. C., Louzir, H., Pirmez, C., Alexander, B., and Brooker, S. (2007). Cutaneous leishmaniasis. Lancet Infect. Dis. 7, 581-596.

Restifo, N. P., Ying, H., Hwang, L., and Leitner, W. W. (2000). The promise of nucleic acid vaccines. Gene Ther. 7, 89-92.

Rey, A., Quartulli, F., Escoubet, L., Sozzani, P., Caput, D., Ferrara, P., and Pipy, B. (1999). IL-13 induces serine phosphorylation of cPLA2 in mouse peritoneal macrophages leading to arachidonic acid and PGE2 production and blocks the zymosan-induced serine phosphorylation of cPLA2 and eicosanoid production. Biochim. Biophys. Acta 1440, 183-193.

Rezvan, H., Rees, R., and Ali, S. (2011). Leishmania mexicana Gp63 cDNA using gene gun induced higher immunity to L. mexicana infection compared to soluble Leishmania antigen in BALB/C. Iran. J. Parasitol. 6, 60-75.

Rivier, D., Shah, R., Bovay, P., and Mauel, J. (1993). Vaccine development against cutaneous leishmaniasis. Subcutaneous administration of radioattenuated parasites protects CBA mice against virulent Leishmania major challenge. Parasite Immunol. 15, 75-84.

Rutschman, R., Lang, R., Hesse, M., Ihle, J. N., Wynn, T. A., and Murray, P. J. (2001). Cutting edge: Stat6dependent substrate depletion regulates nitric oxide production. J. Immunol. 166, 2173-2177.

Salay, G., Dorta, M. L., Santos, N. M., Mortara, R. A., Brodskyn, C., Oliveira, C. I., Barbiéri, C. L., and Rodrigues, M. M. (2007). Testing of four Leishmania vaccine candidates in a mouse model of infection with Leishmania (Viannia) braziliensis, the main causative agent of cutaneous leishmaniasis in the New World. Clin. Vaccine Immunol. 14, 1173-1181.
Saldarriaga, O. A., Travi, B. L., Park, W., Perez, L. E., and Melby, P. C. (2006). Immunogenicity of a multicomponent DNA vaccine against visceral leishmaniasis in dogs. Vaccine 24, 1928-1940.

Saravia, N. G., Escorcia, B., Osorio, Y., Valderrama, L., Brooks, D., Arteaga, L., Coombs, G., Mottram, J., and Travi, B. L. (2006). Pathogenicity and protective immunogenicity of cysteine proteinase-deficient mutants of Leishmania mexicana in non-murine models. Vaccine 24, 4247-4259.

Scharton, T. M., and Scott, P. (1993). Natural killer cells are a source of interferon gamma that drives differentiation of CD4+ T cell subsets and induces early resistance to Leishmania major in mice. J. Exp. Med. 178, 567-577.

Scott, P. (1989). The role of TH1 and TH2 cells in experimental cutaneous leishmaniasis. Exp. Parasitol. 68, 369-372.

Scott, P. (1991). IFN-gamma modulates the early development of Th1 and Th2 responses in a murine model of cutaneous leishmaniasis. J. Immunol. 147, 3149-3155.

Scott, P. (1997). Trinchieri G. IL-12 as an adjuvant for cell-mediated immunity. Semin. Immunol. 9, 285-291.

Scott, P., Natovitz, P., Coffman, R. L., Pearce, E., and Sher, A. (1988). Immunoregulation of cutaneous leishmaniasis. T cell lines that transfer protective immunity or exacerbation belong to different $\mathrm{T}$ helper subsets and respond to distinct parasite antigens. J. Exp. Med. 168, 1675-1684.

Scott, P., Pearce, E., Cheever, A. W., Coffman, R. L., and Sher, A. (1989). Role of cytokines and CD4+ T-cell subsets in the regulation of parasite immunity and disease. Immunol. Rev. 112, 161-182.

Singh, S. P., Reddy, D. C., Rai, M., and Sundar, S. (2006). Serious underreporting of visceral leishmaniasis through passive case reporting in Bihar, India. Trop. Med. Int. Health 11, 899-905.

Singh, V. P., Ranjan, A., Topno, R. K., Verma, R. B., Siddique, N. A., Ravidas, V. N., Kumar, N., Pandey, K., and Das, P. (2010). Estimation of under-reporting of visceral leishmaniasis cases in Bihar, India. Am. J. Trop. Med. Hyg. 82, 9-11.

Sjolander, A., Baldwin, T. M., Curtis, J. M., and Handman, E. (1998). Induction of a Thl immune response and simultaneous lack of activation of a
Th2 response are required for generation of immunity to leishmaniasis. J. Immunol. 160, 3949-3957.

Skeen, M. J., Miller, M. A., Shinnick, T. M., and Ziegler, H. K. (1996). Regulation of murine macrophage IL-12 production. Activation of macrophages in vivo, restimulation in vitro, and modulation by other cytokines. J. Immunol. 156, 1196-1206.

Sosa, M. R., Rosas, L. E., McKenzie, A. N., and Satoskar, A. R. (2001). IL-13 gene-deficient mice are susceptible to cutaneous L. mexicana infection. Eur. J. Immunol. 31, 3255-3260.

Spath, G. F., Garraway, L. A., Turco, S. J., and Beverley, S. M. (2003a). The role(s) of lipophosphoglycan (LPG) in the establishment of Leishmania major infections in mammalian hosts. Proc. Natl. Acad. Sci. U.S.A. 100, 9536-9541.

Spath, G. F., Lye, L. F., Segawa, H. Sacks, D. L., Turco, S. J., and Beverley, S. M. (2003b). Persistence without pathology in phosphoglycandeficient Leishmania major. Science 301, 1241-1243.

Spath, G. F., Lye, L.-F., Segawa, H., Turco, S. J., and Beverley Stephen, M. (2004). Identification of a compensatory mutant (lpg2-REV) of Leishmania major able to survive as amastigotes within macrophages without LPG2-dependent glycoconjugates and its significance to virulence and immunization strategies. Infect. Immun. 72, 3622-3627.

Suffia, I., Reckling, S. K., Salay, G., and Belkaid, Y. (2005). A role for CD103 in the retention of $\mathrm{CD} 4+\mathrm{CD} 25+$ Treg and control of Leishmania major infection. J. Immunol. 174, 5444-5455.

Suffia, I. J., Reckling, S. K., Piccirillo, C. A., Goldszmid, R. S., and Belkaid, Y. (2006). Infected site-restricted Foxp3+ natural regulatory $\mathrm{T}$ cells are specific for microbial antigens. $J$. Exp. Med. 203, 777-788.

Swihart, K., Fruth, U., Messmer, N. Hug, K., Behin, R., Huang, S., Del Giudice, G., Aguet, M., and Louis, J. A. (1995). Mice from a genetically resistant background lacking the interferon gamma receptor are susceptible to infection with Leishmania major but mount a polarized $\mathrm{T}$ helper cell 1-type CD4+ $\mathrm{T}$ cell response. J. Exp. Med. 181, 961-971.

Tabbara, K. S., Peters, N. C., Afrin, F., Mendez, S., Bertholet, S., Belkaid, Y., and Sacks, D. L. (2005). Conditions influencing the efficacy of vaccination with live organisms against Leishmania major infection. Infect. Immun. 73, 4714-4722.
Tewary, P., Sukumaran, B., Saxena, S., and Madhubala, R. (2004). Immunostimulatory oligodeoxynucleotides are potent enhancers of protective immunity in mice immunized with recombinant ORFF leishmanial antigen. Vaccine 22, 3053-3060.

Titus, R. G., Gueiros-Filho, F. J., de Freitas, L. A., and Beverley, S. M. (1995). Development of a safe live Leishmania vaccine line by gene replacement. Proc. Natl. Acad. Sci. U.S.A. 92, 10267-10271.

Titus, R. G., Sherry, B., and Cerami, A. (1989). Tumor necrosis factor plays a protective role in experimental murine cutaneous leishmaniasis. J. Exp. Med. 170, 2097-2104.

Uzonna, J. E., Joyce, K. L., and Scott, P. (2004a). Low dose Leishmania major promotes a transient $\mathrm{T}$ helper cell type 2 response that is downregulated by interferon gammaproducing CD8+ T cells. J. Exp. Med. 199, 1559-1566.

Uzonna, J. E., Späth, G. F., Beverley, S. M., and Scott, P. (2004b). Vaccination with phosphoglycandeficient Leishmania major protects highly susceptible mice from virulent challenge without inducing a strong Th1 response. J. Immunol. 172, 3793-3797.

Uzonna, J. E., Wei, G., Yurkowski, D., and Bretscher, P. (2001). Immune elimination of Leishmania major in mice: implications for immune memory, vaccination, and reactivation disease. J. Immunol. 167, 6967-6974

van Thiel, P. P., Leenstra, T., de Vries, H. J., van der Sluis, A., van Gool, T., Krull, A. C., van Vugt, M., de Vries, P. J., Zeegelaar, J. E., Bart, A., van der Meide, W. F., Schallig, H. D. Faber, W. R., and Kager, P. A. (2010). Cutaneous leishmaniasis (Leishmania major infection) in Dutch troops deployed in northern Afghanistan: epidemiology, clinical aspects, and treatment. Am. J. Trop. Med. Hyg. 83, 1295-1300.

van Zandbergen, G., Bollinger, A., Wenzel, A., Kamhawi, S., Voll, R., Klinger, M., Müller, A., Hölscher, C., Herrmann, M., Sacks, D., Solbach, W., and Laskay, T. (2006). Leishmania disease development depends on the presence of apoptotic promastigotes in the virulent inoculum. Proc. Natl. Acad. Sci. U.S.A. 103, 13837-13842.

van Zandbergen, G., Klinger, M., Mueller, A., Dannenberg, S., Gebert, A., Solbach, W., and Laskay, T. (2004). Cutting edge: neutrophil granulocyte serves as a vector for 
Leishmania entry into macrophages. J. Immunol. 173, 6521-6525.

Vargas-Inchaustegui, D. A., Xin, L., and Soong, L. (2008). Leishmania braziliensis infection induces dendritic cell activation, ISG15 transcription, and the generation of protective immune responses. J. Immunol. 180, 7537-7545.

Varkila, K., Chatelain, R., Leal, L. M., and Coffman, R. L. (1993). Reconstitution of C.B-17 scid mice with $\mathrm{BALB} / \mathrm{c} \mathrm{T}$ cells initiates a $\mathrm{T}$ helper type-1 response and renders them capable of healing Leishmania major infection. Eur. J. Immunol. 23, 262-268.

Velez, I. D., del Pilar Agudelo, S., Arbelaez, M. P., Gilchrist, K., Robledo, S. M., Puerta, J. A., Zicker, F., Berman, J., and Modabber, F. (2000). Safety and immunogenicity of a killed Leishmania (L.) amazonensis vaccine against cutaneous leishmaniasis in Colombia: a randomized controlled trial. Trans. R. Soc. Trop. Med. Hyg. 94, 698-703.

Von Stebut, E. (2007). Immunology of cutaneous leishmaniasis: the role of mast cells, phagocytes and dendritic cells for protective immunity. Eur. J. Dermatol. 17, 115-122.

Wang, Z. E., Reiner, S. L., Hatam, F., Heinzel, F. P., Bouvier, J., Turck, C. W., and Locksley, R. M. (1993). Targeted activation of CD8 cells and infection of beta 2-microglobulindeficient mice fail to confirm a primary protective role for $\mathrm{CD} 8$ cells in experimental leishmaniasis. J. Immunol. 151, 2077-2086.

Wilhelm, P., Ritter, U., Labbow, S., Donhauser, N., Röllinghoff, M., Bogdan, C., and Körner, H. (2001). Rapidly fatal leishmaniasis in resistant C57BL/6 mice lacking TNF. $J$. Immunol. 166, 4012-4019.

Wu, C. Y., Wang, K., McDyer, J. F., and Seder, R. A. (1998). Prostaglandin E2 and dexamethasone inhibit IL12 receptor expression and IL-12 responsiveness. J. Immunol. 161, 2723-2730.

Wu, W., Huang, L., and Mendez, S. (2010). A live Leishmania major vaccine containing $\mathrm{CpG}$ motifs induces the de novo generation of Th17 cells in C57BL/6 mice. Eur. J. Immunol. 40, 2517-2527.

Wu, W., Weigand, L., Belkaid, Y., and Mendez, S. (2006). Immunomodulatory effects associated with a live vaccine against Leishmania major containing $\mathrm{CpG}$ oligodeoxynucleotides. Eur. J. Immunol. 36, 3238-3247.

Wu, W., Weigand, L., and Mendez, S. (2009). The IL-6-deficient mouse exhibits impaired lymphocytic responses to a vaccine combining live Leishmania major and $\mathrm{CpG}$ oligodeoxynucleotides. Can. J. Microbiol. 55, 705-713.

Xu, G., Liu, D., Fan, Y., Yang, X., Korner, H., Fu, Y. X., and Uzonna, J. E. (2007a). Lymphotoxin alpha beta 2 (membrane lymphotoxin) is critically important for resistance to Leishmania major infection in mice. J. Immunol. 179, 5358-5366.

Xu, G., Liu, D., Okwor, I., Wang, Y., Korner, H., Kung, S. K., Fu, Y. X., and Uzonna, J. E. (2007b). LIGHT is critical for IL-12 production by dendritic cells, optimal CD4+ Th1 cell response, and resistance to Leishmania major. J. Immunol. 179, 6901-6909.

Yao, C., Donelson, J. E., and Wilson, M. E. (2003). The major surface protease (MSP or GP63) of Leishmania sp. Biosynthesis, regulation of expression, and function. Mol. Biochem. Parasitol. 132, 1-16.

Yurchenko, E., Tritt, M., Hay, V., Shevach, E. M., Belkaid, Y., and Piccirillo, C. A. (2006). CCR5dependent homing of naturally occurring $\mathrm{CD} 4+$ regulatory $\mathrm{T}$ cells to sites of Leishmania major infection favors pathogen persistence. $J$. Exp. Med. 203, 2451-2460.

Zadeh-Vakili, A., Taheri, T., Taslimi, Y., Doustdari, F., Salmanian, A. H., and Rafati, S. (2004). Immunization with the hybrid protein vaccine, consisting of Leishmania major cysteine proteinases Type I (CPB) and Type II (CPA), partially protects against leishmaniasis. Vaccine 22, 1930-1940.

Zaph, C., Uzonna, J., Beverley, S. M., and Scott, P. (2004). Central memory T cells mediate long-term immunity to Leishmania major in the absence of persistent parasites. Nat. Med. 10 1104-1110.

Zhang, L., Yuan, S., Cheng, G., and Guo, B. (2011). Type I IFN promotes IL10 production from $\mathrm{T}$ cells to suppress th17 cells and th17-associated autoimmune inflammation. PLoS ONE 6, e28432. doi:10.1371/journal.pone. 0028432

Conflict of Interest Statement: The authors declare that the research was conducted in the absence of any commercial or financial relationships that could be construed as a potential conflict of interest.

Received: 25 January 2012; accepted: 03 May 2012; published online: 29 May 2012.

Citation: Okwor I, Mou Z, Liu D and Uzonna J (2012) Protective immunity and vaccination against cutaneous leishmaniasis. Front. Immun. 3:128. doi 10.3389/fimmu. 2012.00128

This article was submitted to Frontiers in Microbial Immunology, a specialty of Frontiers in Immunology.

Copyright (c) 2012 Okwor, Mou, Liu and Uzonna. This is an open-access article distributed under the terms of the Creative Commons Attribution Non Commercial License, which permits noncommercial use, distribution, and reproduction in other forums, provided the original authors and source are credited. 